\title{
YOUTH, PRECARITY AND THE FUTURE Undergraduate housing transitions in Portugal during the economic crisis
}

\author{
David Cairns
}

\section{Introduction}

Like a number of other European countries, Portugal has recently been in a state of economic crisis. One consequence of this condition has been a sharp rise in the national unemployment rate, particularly among the youth population: $23 \%$ in the final quarter of 2010 for those aged between 15 and 24 compared to the equivalent figure of $11.1 \%$ for the total population (INE, 2011). For young people nearing the end of their period of full-time education there is the additional challenge of having to enter the labour market, most of them for the first time, in addition to coping with other aspects of the transition to adulthood, including establishing an autonomous home of their own. This latter issue forms the main focus of this investigation, which concentrates upon exploring housing transitions among undergraduates presently studying at universities in the Lisbon area during the economic crisis period. In respect to the main research question, with prior research suggesting that Portuguese youth already spend long periods residing with their families (Figueiredo et al., 1999), can we anticipate this distended period of inter-generational co-residence to elongate further?

Following a contextualisation of pertinent themes within youth transitions literature and an outline of methodological approach, key results derived from the analysis of quantitative and qualitative data are presented. As might be anticipated, it was found that the majority of the young people surveyed see the economic crisis as having a negative impact upon their incipient housing transitions. Three key influences are emphasised in housing decision-making processes: economic factors, the role of the family and prevailing cultural norms. It is also evident that the level of support these young people receive from their families is extensive. Finally, the responsibility for both causing and for ameliorating the crisis is attributed primarily to the Portuguese government and, to a lesser extent, banks and financial speculators. These findings lead to the conclusion that among those surveyed in most cases housing transitions are likely to continue to be deferred into the future should the economic crisis continue, even after these respondents have completed their studies.

\section{Understanding youth transitions}

The study of transitions to adulthood includes investigation into how young people move between different educational stages and from full-time education to the labour market. To this we can add processes of establishing stable relationships, 
having children and moving out of the parental home and into more or less independent living arrangements (Galland, 1984; 1991). While there is much diversity between different regional and national contexts, in post-industrial societies transitions are generally typified as involving an extended period spent in full-time study followed by considerable difficulties in entering the labour market, with transition outcomes, especially finding a stable job, related by theorists to the mobilisation of individual agency within the structure of social and economic constraints, as well as factors such as social class, gender, ethnicity and spatial location (Roberts et al., 1994: 44; Furlong and Cartmel, 1997: 2-6, 23; Leccardi, 2005: 125; see also Schoon et al., 2001).

Looking at residential transitions, recent decades have witnessed the growing popularity of prolonged stays in the family home, with young people either delaying their exits until an indefinite point in the future or oscillating between living with parents and other more autonomous arrangements. Studies have found that the period of continuous or intermittent inter-generational cohabitation now often stretches into the mid-twenties age range and beyond, particularly but not exclusively in southern European contexts (see, for example, Cherlin et al., 1997; Bendit et al., 1999; Billari et al., 2001; Sgritta, 2001; Aassve et al., 2002; Christie et al., 2002; Ford et al., 2002; Mulder, 2003; Holdsworth, 2006; Billari and Liefbroer, 2007; Ule and Kuhar, 2008).

Important cross-country data specifically pertaining to student transitions also exists, most prominently from the various Eurostudent research projects. Eurostudent III, completed in 2008, found that there is diversity in respect to student living situations across Europe, with private rental accommodation predominant in some northern and central countries and living in the parental home the most common situation in southern and eastern nations. This background information is important in terms of establishing norms in regard to student housing behaviour, e. g. that most Portuguese young people live in the parental home while studying at university. It is also notable that European students tend to have a high level of satisfaction with their housing arrangements, including those who live with their parents (92\% being "very satisfied" in Portugal), suggesting that this condition is not generally perceived as a problem. However we should acknowledge that both living with parents and in rental accommodation, and other less common housing arrangements such as living in university halls of residences, all have their advantages and disadvantages, not only in respect to financial costs but also in terms of fostering independence and autonomy (Orr et al., 2008: 69-82).

Other studies have looked at Portuguese youth transitions from a comparative European perspective, also confirming that the majority of Portuguese young people, particularly those still in education, live with their parents (Guerreiro and Abrantes, 2004; Pappámikail, 2004; Pais et al., 2005). Such studies also make clear that prolonged home-staying among university educated youth population is neither unique to Portugal nor isolated to southern Europe, although the European Commission funded study Families and Transitions in Europe, conducted during 2001-2004 in nine different regions, found that the prevalence of inter-generational co-residence was greatest in Portugal, at 98\% of those surveyed (Biggart, 2005: 49). 
In explaining housing transitions and transitions to adulthood per se, many studies focus upon economic factors or state welfare systems and the manner in which they contribute to the definition and demarcation of various "transition regimes" (Walther, 2006). The role of the family has also been recognised, with generally harmonious inter-generational relationships coupled with the often literal comfort zone of the family home habitually leading towards a disinclination to leave home even when material shortages are not present (Santoro, 2006; Holdsworth, 2006; Lahelma and Gordon, 2008). Studies in Portugal and elsewhere in southern Europe have also historically linked leaving home to marriage, in addition to emphasising the lack of state support for young people who wish to live outside the family (Billari et al., 2001; see also Cavalli and Galland, 1995; Aassve et al., 2002; Naldini, 2003). This process has also been conceptualised as a "privatisation of welfare" (Jones, 1995), wherein the family is presumed to take-on much of the burden of paying for their offspring's post-marital housing costs, thus helping to define the "right" time at which to move out of the parental home as well as the "right" reasons for doing so (Stettersen, 1998; see also Goldscheider and Goldscheider, 1993).

Significantly, all of this theoretical and empirical work refers to the period prior to the onset of the economic crisis in 2008, leading us to ask what will happen to an already distended period of inter-generational co-residence at a time of heightened labour market precarity. The work which follows builds in part upon research conducted by the author in the UK and Ireland on undergraduate transitions during the economic crisis, which has led to a number of tentative conclusions, most notably that these young people are as we might expect fearful about their labour market chances due to the downturn and that heightened recourse to family resources is a common coping strategy. Significantly, it was found that economic justifications were also frequently mobilised as reasons for delaying exits from the parental home (see Cairns, forthcoming; see also Cairns, 2008; 2010).

\section{Methodology}

What follows is a presentation of results emerging from an investigation into the housing transitions of those experiencing the economic crisis rather than an in-depth enquiry into the social, political and economic origins of this situation. Discussion focuses upon one specific national context, Portugal, and those presently studying at university institutions in the capital city, Lisbon. Our sample was structured within the parameters of the most recently available data on the Portuguese student population, as published by the National Statistics Institute (Instituto Nacional de Estatística). These figures show that Portugal had a total of 383,627 students enrolled at various tertiary education institutes in the 2009/10 academic year, with 145,781 studying at Lisbon's 100 public and private tertiary level institutions (INE, 2010: 117-119). A sample of 200 respondents has been constructed using field of study and gender as parameters.

Following an initial pilot conducted with a group of 30 Sociology students at ISCTE - Lisbon University Institute, undergraduates were surveyed at various 
Table 1 Students enrolled in higher education institutions in Portugal by field of study and gender (2009/10) and distribution of cases in final sample

\begin{tabular}{|c|c|c|c|c|c|c|c|c|}
\hline Field of study & $\begin{array}{l}\text { No. of } \\
\text { students }\end{array}$ & Male $\%$ & Female \% & $\begin{array}{c}\text { Total } \\
\text { student } \\
\text { population } \\
\%\end{array}$ & Valid \% & $\begin{array}{l}\text { No. male } \\
\text { cases }\end{array}$ & $\begin{array}{l}\text { No. female } \\
\text { cases }\end{array}$ & Total cases \\
\hline $\begin{array}{l}\text { Business/ } \\
\text { administration }\end{array}$ & 60,118 & 47 & 53 & 16 & 23 & 22 & 24 & 46 \\
\hline Health & 54,765 & 24 & 76 & 14 & - & - & - & - \\
\hline $\begin{array}{l}\text { Engineering/ } \\
\text { related trades }\end{array}$ & 53,374 & 82 & 18 & 14 & 20 & 33 & 7 & 40 \\
\hline $\begin{array}{l}\text { Social/behavioural } \\
\text { sciences }\end{array}$ & 35,848 & 37 & 63 & 9 & 14 & 10 & 18 & 28 \\
\hline Architecture & 27,133 & 65 & 35 & 7 & 10 & 13 & 7 & 20 \\
\hline Arts & 21,086 & 48 & 52 & 5 & 8 & 8 & 8 & 16 \\
\hline Education & 20,750 & 17 & 83 & 5 & - & - & - & - \\
\hline Law & 18,455 & 39 & 61 & 5 & 7 & 5 & 9 & 14 \\
\hline Personal services & 15,670 & 57 & 43 & 4 & 6 & 7 & 5 & 12 \\
\hline Humanities & 13,101 & 39 & 61 & 3 & 5 & 4 & 6 & 10 \\
\hline Life sciences & 10,485 & 34 & 66 & 3 & 4 & 3 & 5 & 8 \\
\hline Computing & 8,193 & 80 & 20 & 2 & 3 & 5 & 1 & 6 \\
\hline Other fields & 44,649 & 40 & 60 & 12 & & - & - & - \\
\hline Total & 383,627 & 47 & 53 & 100 & 100 & 110 & 90 & 200 \\
\hline
\end{tabular}

Source: INE (2010)

faculties of four tertiary education institutions: University of Lisbon, Technical University of Lisbon, Catholic University of Lisbon and the aforementioned ISCTE-IUL. ${ }^{1}$ Ten of the largest student groups at ISCED level 5 (first stage of tertiary education) were sampled, although it was not possible to locate sufficient numbers of respondents in the areas of health and education during the sampling time-frame of October-December $2010 .^{2}$ We can however say with reasonable certainty that the final sample represents $81 \%$ of the Portuguese student population, with proportionate gender representation, although as is always the case in survey research, there may be a number of potential biases which need to be taken into account in the interpretation of results. Most notably, while access to higher education in Portugal has been substantially broadened in the last 30 years, the majority of students still come from families with the most "social, cultural and economic capital at their disposal - the entrepreneurs and executives and the professionals

1 The author would like to thank Dr. Joana Azevedo for invaluable assistance during the fieldwork and also Dr. Graça Cordeiro and Dr. Rita Cachado for help with the pilot and questionnaire design stages respectively, as well as all the respondents who participated in the survey.

2 The "other fields" category includes social services $(7,763)$, journalism $(7,505)$, physical sciences $(6,931)$, environment $(4,974)$, manufacturing $(4,170)$, agriculture $(3,607)$, veterinary $(3,417)$, security $(3,403)$, mathematics $(2,467)$ and transport $(412)$, as well as other small student groups not being differentiated within official statistics (INE, 2010: 118-119). The discrepancy between the gender division in the general student population and within the sample can be explained by the slightly higher numbers of males in the fields included, most prominently "engineering and related trades". Numbers have also been rounded to nearest whole number which may affect totals. 
and managers" (Mauritti and Martins, 2009: 83-85), meaning that the sample is likely to be much more "middle class" than the general youth population. ${ }^{3}$ The baseline parameters also pertain to the 2009/10 academic year as opposed to the 2010/11 academic year in which the actual fieldwork was conducted. The large number of tertiary educational institutions located in the Portuguese capital may also mean that convenience features more prominently in respect to the decision to stay in the parental home than might be the case in other areas of Portugal.

In respect to the "youth" profile of the research, the original intention was to limit the survey to those aged between 18 and 22; however, a small number of students aged between 23 and 25 were ultimately included. The decision to change the age profile was due to the need to include more students from minority backgrounds in terms of country of origin (ultimately amounting to $11.5 \%$ of the sample or 23 cases): when it became apparent during the fieldwork that such students tended to be slightly older than their "Portuguese" counterparts, this change became necessary in order to avoid their exclusion. Other biographical information collected included details of current housing arrangement. This was measured via questions which specifically asked respondents where and with whom they lived at the present time, with the possibility of making multiple responses for those who lived in multi-generational households or in less easily defined arrangements. It was found that $83 \%$ lived exclusively in the family home, a significantly higher proportion compared to the $56 \%$ of undergraduates living with parents across Portugal cited in Eurostudent III (Orr et al., 2008: 73). Those in other arrangements either shared a house or flat with friends (11\%) or lived alone (6\%). While students can occupy intermediate housing situations, e. g. living outside the family home during the week and returning to parents at the weekend, none of the respondents included in the sample reported that they were in such a situation. In regard to marital status, all cases were single but $20 \%$ had non-cohabiting partners and three had children.

Besides these biographical details, a number of key quantitative measures were included in the questionnaire, along with further open "qualitative" questions, covering issues such as domestic life, advantages and disadvantages of present place of residence and future housing aspirations. Considering that all of the respondents were presently in education, and most still living at home with their parents, the wording of questions on housing transitions was necessarily hypothetical, i.e. regarding future plans rather than past actions (see table 2). Assessing the impact of the economic crisis was also a prominent part of the questionnaire. In respect to this theme, the pilot provided not only the opportunity to fine-tune questions but also obtain a better idea of what actually mattered to undergraduates in respect to their housing transitions. It was obvious from the

3 If we accept parental occupations as an indicator of socio-economic family background, using "highest" occupation of father, mother or guardian, coded into ISCO-88 categories and later canalised into broader categories, $60 \%$ of respondents had one or more parents with "skilled non-manual" occupations, 17\% from "skilled manual", 11.5\% from "semi/unskilled non-manual" and $11.5 \%$ from "semi/unskilled manual". 
Importance of various reasons to leave home

\begin{tabular}{lc}
\hline Reason & \% Important (very important) \\
\hline Have enough money & $95(74)$ \\
Have a secure job & $82(58)$ \\
Need personal space & $80(40)$ \\
Find the right place & $75(38)$ \\
Feel it is time to go & $75(35)$ \\
Have a relationship & $63(28)$ \\
Have children & $62(38)$ \\
End of studies & $51(26)$ \\
To move to a different place & $35(11)$ \\
Begin studies & $33(16)$ \\
Sick of family & $29(12)$ \\
Friends leaving home & $18(4)$ \\
Siblings leaving home & $15(4)$
\end{tabular}

feedback obtained that more attention needed to be paid to the role of the economic crisis, leading to the inclusion of questions on responsibility for causing and ameliorating the crisis.

In respect to analysis, both SPSS and Nvivo were employed in interpreting the data. SPSS was used in respect to the responses made to the quantitative questions, while the answers to the open questions were coded into Nvivo. In the latter case, a series of nodes were then created out of which further variables for use in the quantitative analysis were produced.

\section{Housing decision-making}

Bearing in mind the importance of having the "right" reasons for leaving home (Stettersen, 1998), investigation was made of the housing decision-making process. With only a small minority of respondents living outside the parental home $(17 \%)$, rather than ask about actual residential transitions, thirteen hypothetical justifications for leaving home were presented to all respondents, home-leavers and home-stayers alike.

Table 2 provides an illustration of the responses obtained, ordered from reasons to leave home considered most to least important. "Have enough money" is overwhelmingly regarded as the most important justification (95\%), with "Have a secure job" the second most important (82\%). This is an interesting outcome in respect to telling us what matters, and what doesn't matter, for our respondents when thinking about leaving home. Furthermore, that having money and job security predominate at a time when both are in short supply means the economic crisis can make a much greater impact that it might have in circumstances wherein a greater range of considerations and resources are taken into account. For instance, prior research with Irish undergraduates has shown that the utilisation of social capital generated in peer networks and the 
social learning of housing independence from siblings can be of pivotal importance to leaving home, even for those without recourse to significant economic resources (see Cairns and Growiec, 2011). It is also notable that educational reasons, i.e. beginning or ending studies, did not feature prominently, perhaps reflecting the "convenience" of studying in Lisbon. A less predictable finding is the relative lack of importance awarded to having a relationship and children, particularly the low numbers who thought these two reasons were "very important": $28 \%$ and $38 \%$ of respondents respectively.

In interpreting the answers to this question we should also consider less visible cultural factors which may also have an impact on housing decision-making, most obviously that the shared experience of home-staying makes living in the family home a cultural norm for students, helping to remove any potential stigma from this residential choice. We also need to consider another aspect of holding an economic-centric view of leaving home, namely the level at which housing aspirations are being set: are housing goals out of respondents' immediate and possible future "price ranges"? This issue has been explored via an open question on the theme of "ideal" future housing situation. ${ }^{4}$ With the assistance of Nvivo, we can observe that $86 \%$ of the valid responses made could be considered hard to reach if not necessarily unrealistic aspirations, for instance:

A house close to my job and sufficiently spacious, full of all the necessary prerequisites considered important at this time. [Female business student, 20, lives with family, skilled non-manual parents]

In a furnished house that I like and with all the luxuries that charactarise my personality; an apartment with my boyfriend in an area like Cascais or Oeiras. [Female business student, 22, lives with family, skilled non-manual parents]

Close to my family, in a house with good conditions and in an area that is calm and unpolluted. [Male business student, 18, lives with family, skilled non-manual parents]

After I finish my course, I want to live in a little apartment in the centre of the city or a loft (that is my dream). It has to be a large space that I can decorate freely. But I don't think that Lisbon has this type of housing. [Female business student, 23, lives with family, skilled non-manual parents]

A house near to my present house and close to my friends. My preference would be a cottage, situated in a place that is peaceful. [Male engineering student, 19, lives with family, semi/unskilled non-manual parents]

4 The original wording of this question was: "In your own words, what would be your ideal housing situation in the future?" 
I want to live in the same area I live in now, but with financial independence and without losing contact with my family. A large house. [Male engineering student, 22, lives with family, skilled non-manual parents]

A three bedroom apartment in a safe area, and with the financial means to keep it. [Female social communication student, 21, lives with family, skilled non-manual parents]

As is readily apparent, these young people tend to have for the most part reasonable aspirations, albeit often quite specific demands such as staying close to their families or a living in a nice neighbourhood. However, even modest plans may still go unrealised for some considerable time given the on-going economic difficulties in Portugal. To imply that these individuals are somehow "wrong" to have such desires would be unfair, but it is evident that these plans, largely made in terms of the immediate period after finishing tertiary education, show no signs of having been adapted to an increasingly precarious reality.

\section{Family support and domestic life}

It has been established elsewhere that parents often provide a high level of support to their offspring during the transition to adulthood (Swartz and O'Brien, 2009; see also Brannen et al., 2004). Prior studies show that parental largess can be frequent and come in different forms (Lahelma and Gordon, 2008). Studies in Portugal also show that parents, as opposed to extended kin members, are the main source of support, with this support often following gender dynamics (Wall et al., 2001; see also Sweeting et al., 1998). With so many young people residing in the parental home for so long, it becomes necessary to ask questions about their domestic lives, namely what it is that these young people actually do or not do while living at home?

It is immediately apparent from table 3 that not only do these respondents receive high levels and a broad range of family support but they also demonstrate a high degree of personal autonomy, whether living with or without their parents. This extends to areas such as having access to a car and, presumably during summer, a holiday home. There are in fact minimal differences between responses for those living with and without their families beyond car access, unlimited internet access and being able to invite friends to visit; on these two last measures, those living at home actually scored significantly higher.

Moving on to another key area of domestic life, that of household chores, Guerreiro and Abrantes (2004) found that many of the young males interviewed as part of their study had little involvement in such activities.

Table 4 explores this issue not only in respect to living arrangement but also gender. The range of items includes areas such as laundry, cleaning and tidying the house and doing the grocery shopping, as well as cooking for both oneself and others. The results do partly support the claim that young males, in this case exclusively those from higher education backgrounds, don't engage in housework to the 
Family support and domestic life

\begin{tabular}{lccc}
\hline & & $\%$ & \\
\cline { 2 - 4 } & Living with family & Living independently & All \\
\hline Family support & & & 77 \\
Financial support & 79 & 71 & 92 \\
Emotional support & 92 & 91 & 64 \\
Help with studies & 63 & 66 & 74 \\
Help with career & 73 & 80 & 67 \\
Access to car** & 73 & 41 & 62 \\
Access to holiday home & 65 & 50 & 90 \\
Domestic life & & & 88 \\
Own room & 90 & 88 & 98 \\
Decide own social hours & 87 & 91 & 95 \\
Decide social places & 98 & 100 & 98 \\
Place to study & 94 & 100 & 96 \\
Internet without limits & & 92 & \\
Invite friends** & 99 & 88 & \\
\hline
\end{tabular}

${ }^{* *}$ Pearson chi square level of significance $=$ less than .005

${ }^{* * *}$ Pearson chi square level of significance $=0$

Table 4 Living arrangement, gender and domestic chores

\begin{tabular}{lccc}
\hline & & $\%$ & \\
\cline { 2 - 4 } & Living with family & Living independently & All \\
\hline Laundry** & 30 & 58 & 35 \\
Tidying the house & 73 & 75 & 74 \\
Cleaning & 58 & 53 & 57 \\
Shopping & 67 & 66 & 67 \\
Cooking for self & 79 & 81 & 51 \\
Cooking for others* & 54 & 34 & All \\
\hline & Male & Female & 35 \\
& 39 & 43 & 74 \\
Laundry* $_{\text {Tidying the house }}^{*}$ & 69 & 80 & 57 \\
Cleaning & 55 & 61 & 67 \\
Shopping & 64 & 81 & 80 \\
Cooking for self* & 74 & 60 & 51 \\
Cooking for others & 44 & & \\
\hline
\end{tabular}

${ }^{*}$ Pearson chi square level of significance $=$ less than .05

${ }^{* *}$ Pearson chi square level of significance $=$ less than .005

same extent as their female counterparts. This is true in respect to laundry, where the female respondents were more active, although only a minority of all respondents undertook this chore, and cooking for both self and others. More obviously, we can see that those who live independently of their families are much more likely to do their own washing, but less likely to cook for other people. That those living away from home have similar levels of support also suggests that their families 
continue to help even when their children are not living at home, a finding consistent with the results of a recent study in Catalonia (Merino and Garcia, 2006:36-37).

\section{Housing transitions and the economic crisis}

This final part of our discussion returns to the main theme of the article and asks what impact the economic crisis is making upon the housing transitions of these young people. Our results show that $70 \%$ of all respondents felt that the crisis would have a negative impact upon their future housing situation, with $59 \%$ specifically stating that they were planning to stay in their present place of residence because of the crisis.

Exploring these results further, table 5 provides breakdowns by gender, "social class" (with parents in skilled or semi/unskilled professions as proxy indicator) using a series of binary logistic regression analyses, with future housing prospects (positive or negative) and remaining in present housing situation as dependent variables. As we can see, there are significant differences in respect to gender and anticipated impact upon housing prospects (Nagelkerke $\mathrm{R}^{2}=.54$ ), with female respondents appearing to be more fearful than their male counterparts; however, "social class" and living arrangement appear to make no significant impact. In interpreting these results, the fact that these young women feel more vulnerable during the economic crisis in respect to their housing transitions is consistent with other indicators which suggest that there may be a gender dimension to the present malaise, most obviously the fact that unemployment figures have recently been higher for women: $29.7 \%$ for those aged between 15 and 24 compared to the male equivalent figure of $22.6 \%$ (INE, 2011).

The remaining part of this analysis focuses upon various aspects of the economic crisis itself, particularly in respect to responsibility for causing and fixing the crisis (table 6).

Even bearing in mind that respondents had the freedom to nominate as many "guilty parties" as they saw fit, we can see that the "Portuguese government" are the clear "winners" in both categories, although slightly more respondents (86\%) thought that their government had responsibility for fixing the crisis than for causing it $(74 \%)$; in the case of the "Portuguese people", the same pattern of results emerged, and to a greater extent. The reverse trend is noticeable elsewhere, not only in regard to banks and financial speculators but also the previous generation, i. e. the parental generation of these respondents. A total of $7 \%$ thought they were a cause but only $1 \%$ felt that they had the responsibility of contributing to the improvement of this situation. One interpretation of this latter outcome could be a reluctance to be critical of a parental generation which has, as previously illustrated in table 3, provided such extensive support to its children.

The respondents themselves, in response to an open question on how they expected the economic crisis to influence their housing situations, provided uniformly negative responses: ${ }^{5}$

5 The original wording of this question was: "How can the economic crisis have an influence on your housing situation?"

SOCIOLOGIA, PROBLEMAS E PRÁTICAS, n. ${ }^{\circ}$ 66, 2011, pp. 9-25 
Housing transition prospects by gender, "social class" and living arrangement

\begin{tabular}{l|c|c|c|c}
\hline \multirow{2}{*}{} & \multicolumn{2}{|c|}{ Affect housing prospects } & \multicolumn{2}{c}{ Remain in present housing situation } \\
\cline { 2 - 5 } & $B$ & $\operatorname{Exp}(ß)$ & $\beta$ & Exp (ß) \\
\hline Gender (male) & $-.888^{* *}$ & .411 & -.047 & .954 \\
Class (skilled) & -.128 & .880 & -.122 & .886 \\
Living (with family) & .364 & 1.439 & .387 & 1.473 \\
\hline
\end{tabular}

${ }^{* *}$ Pearson chi square level of significance $=$ less than .005

Table 6

Responsibility for the economic crisis in Portugal

\begin{tabular}{lcc}
\hline & For causing the crisis $(\%)$ & For fixing the crisis $(\%)$ \\
\hline Portuguese government & 74 & 86 \\
Portuguese people & 40 & 82 \\
European Union & 16 & 36 \\
Banks & 37 & 24 \\
Financial speculators & 34 & 12 \\
Previous generation & 7 & 1 \\
US government & 17 & 10 \\
Others & 7 & 6 \\
\hline
\end{tabular}

With the crisis, there are fewer jobs, and soon, less chance of finding a secure job. Without a job, you don't have any money, and without money, you don't have somewhere of your own to live. [Female business student, 20, living with family, skilled non-manual parents]

If you don't have a job you don't have any money. If you don't have money, you can't buy or rent a house. [Female literature student, 18, lives with friends, skilled non-manual parents]

The crisis can determine my professional situation in the future, and this way make it impossible to have the necessary conditions in which to find a desirable residence. [Male, engineering student, 22, lives with family, skilled non-manual parents]

Lower salaries and, consequentially, housing of worse quality. [Female, law student, 21, lives with family, skilled non-manual parents]

Prices, they are always going up, and each time it becomes more difficult to attain the means to afford a home in the future. Salaries are low in Portugal and it's going to be difficult to be able to acquire the house that I want. [Female, social communication student, 21, lives with family, skilled non-manual parents] 
We can see that these respondents, all from different educational backgrounds, are making an explicit link between the declining fortunes of the Portuguese economy and their own housing prospects, not to mention the possibility of finding secure employment. It is also apparent in the latter two cases that as previously discussed, the issue of housing quality is important; and this is evidently something under threat because of the economic crisis. But these responses are oddly incongruent with what was said in respect to housing aspirations: even though they know that the present economic situation is bad and their future economic outlook is bleak they maintain their high ideal housing aspirations.

What is also apparent is the linearity of the thinking on display: declining economy, declining job prospects and declining housing aspirations; and in that specific order. The above cases were also far from exceptional: using Nvivo, it was possible to identify $92 \%$ of the valid responses to this question as making direct linkages between the state of the national economy and personal housing situation. This finding is perhaps unexpected, considering that youth transitions have tended to been conceptualised in terms of dislinearity (see, for example, Walther, 2006). Housing transitions have more specifically been defined in terms of their fluidity: "boomerang" movement back and forward between different housing arrangements, and varying levels of autonomy (Molgat, 2002: 135; Holdsworth and Morgan, 2005: 6; see also Billari et al., 2008). It may well be that this particular logic does not apply to how these young people think about their own declining prospects, which seem to be unravelling in a fixed sequence. There is certainly no suggestion that they are likely to accept intermediate housing arrangements when aspirations cannot be reached.

It is finally worth remarking on the high level of homogeneity in respect to the answers of these respondents across the board, as well as the fact that the majority $(83 \%)$ have made the same housing "choice", i.e. to remain in the family home. While this lack of diversity in housing situation leads to an inability to construct typologies, an approach followed in other studies, most notably Ford et al. (2002), this may also be a reflection of the relatively narrow geo-demographic range of the sample. For this reason, we must temper our deductions with the realisation that other realities may exist among other sections of the Portuguese youth population and/or in different locales. It has however been suggested elsewhere that leaving home is simply not a priority or an "important marker" of youth independence (Mulder, 2009: 203). This is confirmed by analysis of European Social Survey data from 2006 (Nico, 2010). This data illustrated that across Europe, both parenthood $(45 \%)$ and having a full-time job (49\%) were regarded as more important than residential autonomy $(40 \%)$, but in respect to the Portuguese context, the latter was generally of even lesser important compared to peers in other countries. In fact, staying at home was perceived as a "rational" or "strategic" choice to save money towards eventually buying a home of one's own or making funds available for consumer spending and lifestyle maintenance (Nico, 2008: 2; see also Pais, 2003). 


\section{Conclusion: inter-generational cohabitation, precarity and the future}

In answer to the question set at the beginning of this article, we can say that the young people surveyed certainly tend to perceive the economic crisis as having a negative impact upon their capacity to enact housing transitions, meaning a potential further prolongation of their stays in the parental home. That the majority of respondents have not made the transition to more autonomous households and are presently living with their families will come as no surprise to those familiar with contemporary youth in Portugal. Furthermore, when faced with what feel like hostile labour market conditions and perhaps also a housing market unresponsive to their needs, not to mention a generally supportive family, deciding to remain in the parental home seems a logical preference; a choice culturally legitimised by the fact that this is a shared generational experience.

Merely confirming the popularity of inter-generational cohabitation while studying, whether for reasons of cultural normality, convenience, economic expediency or emotional stability, does not constitute adding major insight into understanding the housing transitions of our subject group. What is more interesting is the potential impact we have observed being made upon the future capacity to enact housing transitions due to a perception of heightening precarity, particularly within the labour market. We can hence see that many respondents might not be able to establish an autonomous household after they have completed their studies and/or have entered the labour market, and that they may have to remain at home at a time when it might not be so desirable, or "normal", to be doing so. This is an important nuance, and an issue which invites further investigation, particularly in areas not exhaustively studies here such as different gender experiences. And the longer the economic crisis continues, particularly while leaving home continues to be imagined as dependent upon reaching increasingly hard to reach economic goals, the more housing transitions are likely to be deferred into the future, leading us to suggest that this might also be an issue in need of long-term investigation.

\section{References}

Aassve, Arnstein, Francesco C. Billari, Stefano Mazzuco, and Fausta Ongaro (2002), "Leaving home: a comparative analysis of ECHP data", Journal of European Social Policy, 12, pp. 259-275.

Bendit, Rene, Wolfgang Gaiser, and Jan Marbach (1999), Youth and Housing in Germany and the European Union. Data Trends on Housing. Biographical, Social and Political Aspects, Opladen, Leske \& Budrich.

Biggart, Andy (2005), Families and Transitions in Europe. Final Report, Coleraine, University of Ulster.

Billari, Francesco C., Dimitar Philipov, and Pau Baizán (2001), “Leaving home in Europe: the experience of cohorts born around 1960", International Journal of Population Geography, 7, pp. 339-356. 
Billari, Francesco C., and Aart C. Liefbroer (2007), “Should I stay or should I go? The impact of age norms on leaving home", Demography, 44, pp. 181-198.

Billari, Francesco C., Alessandro Rosina, Rita Ranaldi, and Maria C. Romano (2008), "Young adults living apart and together (LAT) with parents: a three-level analysis of the Italian case", Regional Studies, 42 (5), pp. 625-639.

Brannen, Julia, Peter Moss, and Ann Mooney (2004), Working and Caring over the Twentieth Century. Change and Continuity in Four-Generation Families, Houndmills, Palgrave Macmillan.

Cairns, David (2008), “Moving in transition: an exploration of Northern Ireland youth and geographical mobility", Young, 16 (3), pp. 227-249.

Cairns, David (2010), "Pulled-in or pushed out? The economic crisis and youth migration in Belfast", conference paper presented at European Sociological Association Youth and Generation Network Midterm Conference, Youth Economy and Society, September 2010, Disley, England.

Cairns, David (forthcoming), “I wouldn't want to stay here: economic crisis and youth mobility in Ireland", International Migration.

Cairns, David, and Katarzyna Growiec (2011), “Learning insularity: social learning, social capital and staying at home among European youth", in Z. Beckerman, and T. Geisen (eds.), Migration, Minorities, and Learning. Understanding Cultural and Social Differences in Education, New York, Springer.

Cavalli, Alessandro, and Olivier Galland (eds.) (1995), Youth in Europe. Social Change in Western Europe, London, Pinter.

Cherlin, Andrew J., Eugenia Scabini, and Giovanna Rossi (1997), "Still in the nest: delayed home leaving in Europe and the United States", Journal of Family Issues, 18, pp. 572-575.

Christie, Hazel, Moira Munro, and Heidi Rettig (2002), "Accommodating students", Journal of Youth Studies, 5, pp. 209-235.

Figueiredo, Alexandra, Catarina L. da Silva, and Vítor S. Ferreira (1999), Jovens em Portugal. Análise Longitudinal de Fontes Estatísticas, Oeiras, Celta Editora.

Ford, Janet, Julie Rugg, and Roger Burrows (2002), “Conceptualising the contemporary role of housing in the transition to adult life in England", Urban Studies, 39, pp. 2455-2467.

Furlong, Andy, and Fred Cartmel (1997), Young People and Social Change. Individualisation and Risk in Late Modernity, Buckingham, Open University Press.

Galland, Olivier (1984), Les Jeunes, Paris, Éditions La Découverte.

Galland, Olivier (1991) Sociologie de la Jeunesse. L'Entreé dans la Vie, Paris, Armand Colin.

Goldscheider, Frances K., and Calvin Goldscheider (1993), Leaving Home before Marriage. Ethnicity, Familism and Generational Relationships, Madison, University of Wisconsin Press.

Guerreiro, Maria das Dores, and Pedro Abrantes (2004), “Moving into adulthood in a southern European country: transitions in Portugal", Portuguese Journal of Social Sciences, 3 (3), pp. 191-209.

Holdsworth, Clare, and David Morgan (2005), Transitions in Context. Leaving Home, Independence and Adulthood, Maidenhead, Open University Press.

Holdsworth, Clare (2006), “Don't you think you're missing out, living at home? Student 
experiences and residential transitions", The Sociological Review, 54, pp. 495-519.

INE - Instituto Nacional de Estatística (2010), Anuário Estatístico de Portugal, Edição 2010, Lisbon, INE.

INE - Instituto Nacional de Estastística (2011), Unemployment Rate November 2010, http://www.ine.pt/xportal/xmain?xpid=INE\&xpgid=ine_destaques\&DESTAQUESd est_boui $=104784378 \& D E S T A Q U E S m o d o=2$

Jones, Gill (1995), Leaving Home, Buckingham, Open University Press.

Lahelma, Elina, and Tuula Gordon (2008), “Resources and (in(ter))dependence: young people's reflections on parents", Young, 16 (2), pp. 209-226.

Leccardi, Carmen (2005), "Facing uncertainty: temporality and biographies in the new century", Young, 13 (2), pp. 123-146.

Mauritti, Rosário, and Susana da Cruz Martins (2009), “Higher education students: contexts and social origins", in António Firmino da Costa, Fernando Luís Machado, and Patrícia Ávila, Knowledge and Society. Portugal in the European Context, vol. III, Oeiras, Celta Editora, pp. 81-97.

Merino, Rafael, and Maribel Garcia (2006), “Emancipation enlargement and the acquisition of autonomy by young people in Catalonia", Young, 14 (1), pp. 33-47.

Molgat, Marc (2002), “Leaving home in Quebec: theoretical and social implications of (im)mobility among youth", Journal of Youth Studies, 5 (2), pp. 135-152.

Mulder, Clara H. (2003), "The housing consequences of living arrangement choices in young adulthood", Housing Studies, 18 (5), pp. 703-719.

Mulder, Clara H. (2009), "Leaving the parental home in young adulthood", in A. Furling (ed.), Handbook of Youth and Young Adulthood, Abingdon, Routledge, pp. 203-210.

Naldini, Manuela (2003), The Family in the Mediterranean Welfare States, London, Frank Cass.

Nico, Magda L. (2008), “(Des)incentivo ao arrendamento por jovens”, in R. M. Laureano, and H. M. Soares (eds.), Perspectivas do Crédito à Habitação, Lisbon, Edições Sílabo.

Nico, Magda L. (2010), “Individualized housing careers in early adulthood: conditions and constraints in a familistic society", Sociological Research Online, 15 (1), http: //www. socresonline. org. uk /15/1/6. html

Orr, Dominic, Klaus Schnitzer, and Edgar Frackmann (2008), Social and Economic Conditions of Student Life in Europe. Synopsis of Indicators. Final Report. Eurostudent III 2005-2008, Bielfield, W. Bertlesmann Verlag.

Pais, José Machado (2003), "The multiple faces of the future in the labyrinth of life", Journal of Youth Studies, 6 (2), pp. 115-126.

Pais, José Machado, David Cairns, and Lia Pappámikail (2005), “Youth in Europe: a portrait of diversity", Tempo Social, 17 (2), pp. 109-140.

Pappámikail, Lia (2004), “Relações intergeracionais, apoio familiar e transições juvenis para a vida adulta em Portugal", Sociologia, Problemas e Práticas, 46, pp. 91-116.

Roberts, Ken, S. C. Clark, and Clare Wallace (1994), "Flexibility and individualisation: a comparison of transitions into employment in England and Germany", Sociology, 28, pp. 31-54.

Santoro, Monica (2006), “Living with parents: a research study on Italian young people and their mothers", in Carmen Leccardi, and Elisabetta Ruspini (eds.), A New Youth? Young People, Generations and Family Life, Aldershot, Ashgate, pp. 146-163. 
Schoon, Ingrid, Andrew McCulloch, Heather E. Joshi, Richard D. Wiggings, and John Bynner (2001), "Transitions from school to work in a changing social context", Young, 9 (1), pp. 4-22.

Sgritta, Giovanni B. (2001), Family and Welfare Systems in the Transition to Adulthood. An Emblematic Case Study, working papers of the Institute for Social and Economic Research, paper 2001-18, Colchester, University of Essex.

Stettersen, Richard A. (1998), "A time to leave home and a time never to return? Age constraints on the living arrangements of young adults", Social Forces, 76 (4), pp. 1373-1400.

Swartz, Teresa T., and Kirsten B. O’Brien (2009), “Intergenerational support during the transition to adulthood", in A. Furling (ed.), Handbook of Youth and Young Adulthood, Abingdon, Routledge, pp. 217-225.

Sweeting, Helen, Patrick West, and Martin Richards (1998), “Teenage family life, lifestyles and life chances: associations with family structure, conflict with parents and joint family activity", International Journal of Law, Policy and the Family, 12, pp. 15-46.

Ule, Mirjana, and Metka Kuhar (2008), “Orientations of young adults in Slovenia toward the family formation", Young, 16 (2), pp. 153-183.

Wall, Karin, Pedro Vasconcelos, Sofia Aboim, and Vanessa Cunha (2001), "Families and informal support networks in Portugal: the reproduction of inequality", Journal of European Social Policy, 11 (2), pp. 213-233.

Walther, Andreas (2006), "Regimes of youth transitions: choice, flexibility and security in young people's experiences across different European contexts", Young, 14 (2), pp. 119-139.

David Cairns. Senior researcher at CIES-IUL.E-mail: david.cairns@iscte.pt

\section{Resumo / abstract / résumé / resumen}

Juventude, precariedade e futuro: transições habitacionais sobrevalorizadas em Portugal durante a crise económica

O artigo analisa as transições de habitação/habitacionais dos jovens que estudam em universidades em Lisboa, Portugal. Com a juventude portuguesa a ficar em casa dos pais por períodos prolongados, a presente discussão questiona a probabilidade de a crise económica ter um novo impacto no comportamento habitacional. Os temas explorados incluem tomadas de decisão habitacionais, envolvimento nas tarefas domésticas e apoio recebido dos pais. Os resultados confirmam que a maioria destes jovens tendem a prolongar a estadia em casa dos pais devido à crise, com as suas escolhas habitacionais ligadas ao dinheiro e à estabilidade no emprego.

Palavras-chave crise económica, transições habitacionais, Portugal, juventude. 
Youth, precarity and the future: undergraduate housing transitions in Portugal during the economic crisis

This article examines the housing transitions of young people studying at universities in Lisbon, Portugal. With Portuguese youth already staying within the parental home for prolonged periods, the present discussion asks if the economic crisis is likely to make a further impact upon the housing behaviour of respondents. Issues explored include housing decision-making, involvement in domestic tasks and support received from parents. The results confirm that the majority of these young people intend to prolong their stays in the parental home due to the crisis, with their housing choices strongly linked to financial considerations and employment stability.

Keywords economic crisis, housing transitions, Portugal, youth.

Jeunesse, précarité et avenir: transitions habitationnelles surestimées au Portugal durant la crise économique

L'article analyse les transitions du logement des jeunes qui étudient dans les universités de Lisbonne, au Portugal. Alors que les jeunes portugais tendent à vivre plus longtemps chez leurs parents, cet article se demande si la crise économique ne pourrait pas avoir un nouvel impact sur le comportement de la jeunesse en matière de logement, en abordant les thèmes de la prise de décision sur le lieu d'habitation, de la participation aux tâches ménagères et de l'aide reçue des parents. Les résultats confirment que la plupart de ces jeunes tendent à prolonger leur séjour chez leurs parents à cause de la crise, leurs choix en matière de logement étant liés à l'argent et à la stabilité de l'emploi.

Mots-clés crise économique, transitions habitationnelles, Portugal, jeunesse.

Juventud, precariedad y futuro: transiciones habitacionales sobrevaloradas en Portugal durante la crisis económica

El artículo analiza las transiciones de habitación/habitacionales de os jóvenes que estudian en universidades en Lisboa, Portugal. Con la juventud portuguesa permaneciendo en casa de los padres por periodos prolongados, la presente discusión cuestiona la probabilidad de que la crisis económica tenga un nuevo impacto en el comportamiento habitacional. Los temas revisados incluyen las decisiones habitacionales elegidas, compromiso en las tareas domésticas y apoyo recibido de los padres. Los resultados confirman que la mayoría de estos jóvenes tienden a prolongar la estancia en casa de los padres debido a la crisis, siendo sus elecciones habitacionales dependientes del dinero y de la estabilidad en el empleo.

Palabras-clave crisis económica, transiciones habitacionales, Portugal, juventud. 